MAGNARTO प्राम

(4)

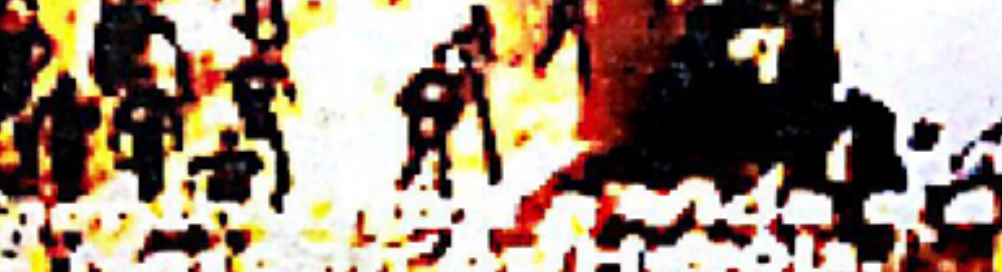

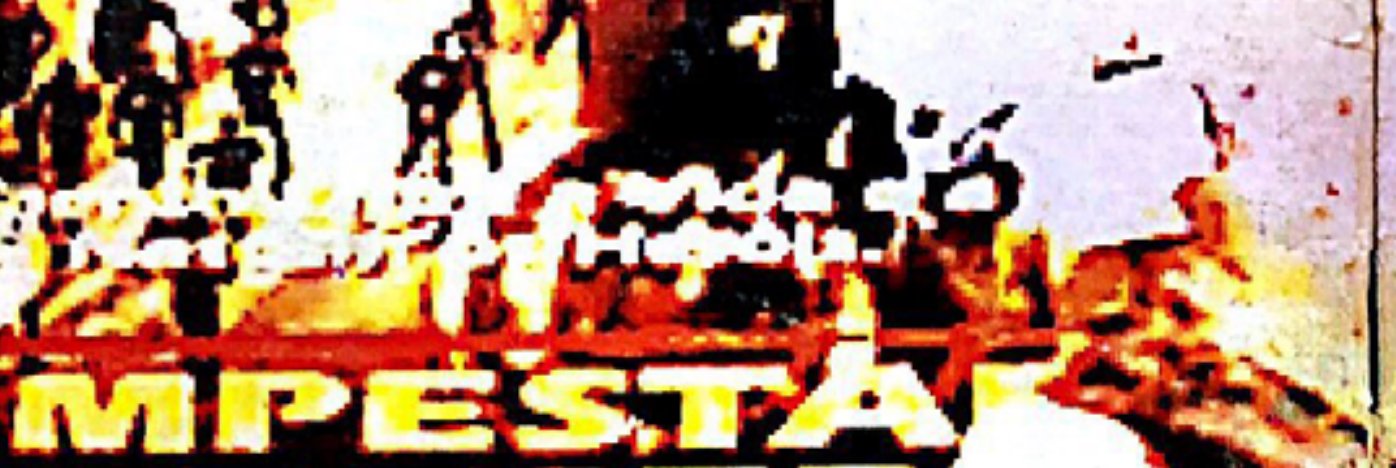

$2 D S T=15$

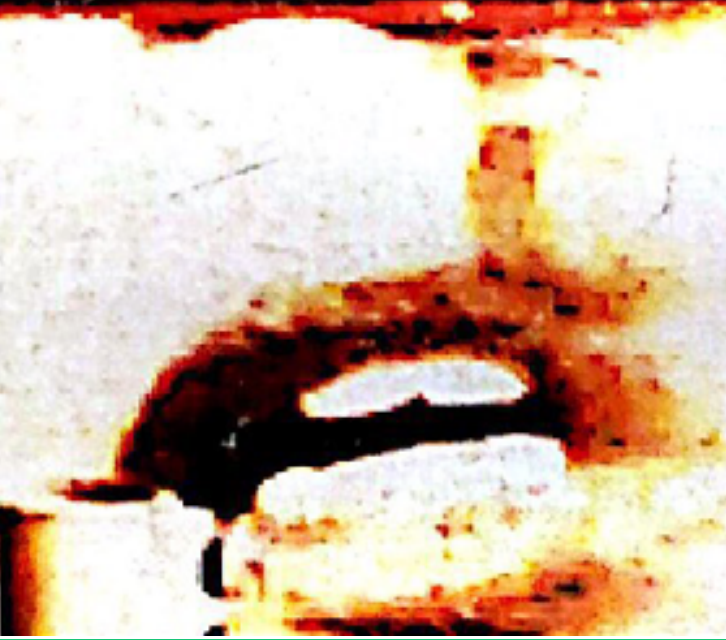

A estética do imaginário no cinema

Demian Garcia e André A. Medeiros P. 94

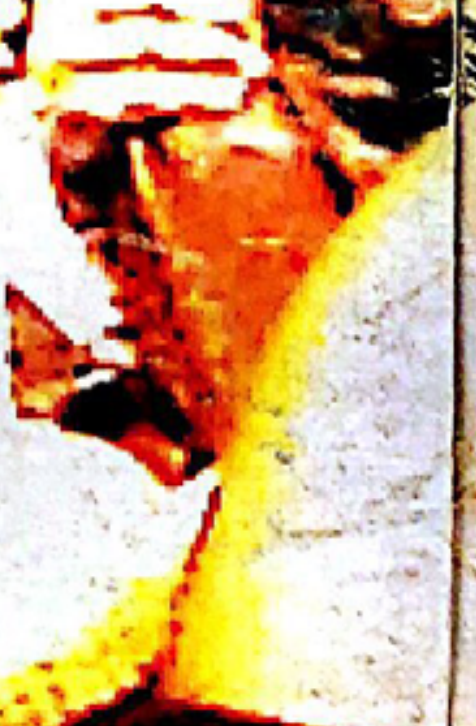

$+$

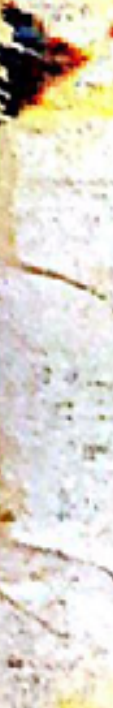

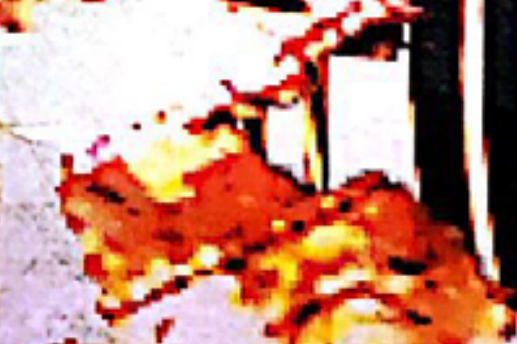

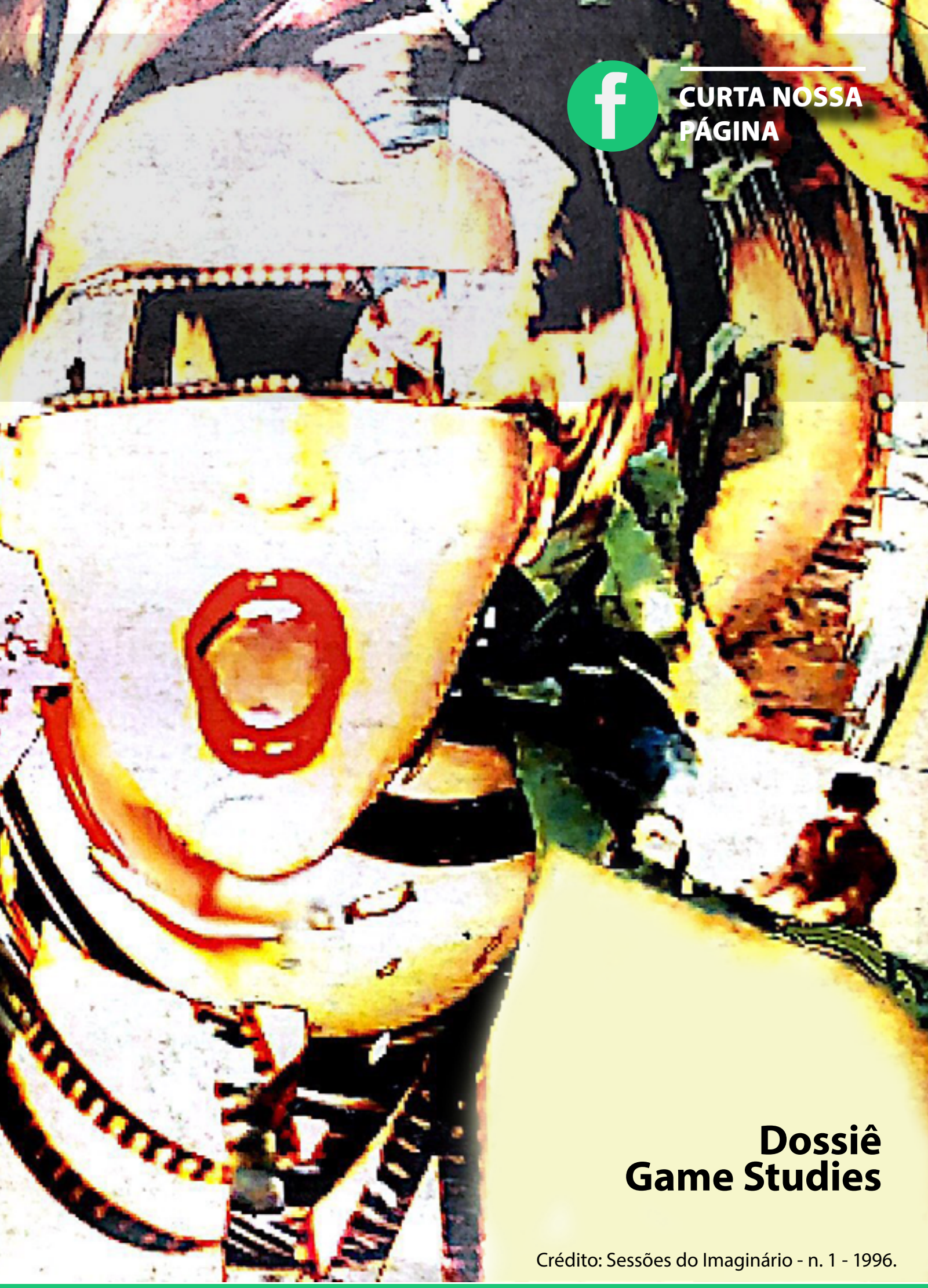

Materialidades fílmicas, magia e montagem

Ednei de Genaro

P. 112

Videogames, transgressão e criatividade no Brasil

Emmanoel Ferreira 


\section{Materialidades filmicas, magia e montagem: reflexões sobre a montagem cinematográfica em Interface (1995)}

Filmic materialities, magic and montage: Reflections on the cinematographic montage in Interface (1995)

Ednei de Genaro' $[\pi$

\section{Resumo}

Realizamos uma interpretação da obra Interface (1995), obra em que Harun Farocki procura compreender seus próprios gestos e ambiente, convocando-nos a fazer seis breves reflexões, que relacionam questões acerca de materialidades fílmicas, magia e montagem no contexto da sociedadeindustrial. Vem a sercuriosa a forma como cineasta desdobrou seu humanismo crítico. Nele, imagens e palavras ganham intensa horizontalidade e transduções. Um mundo humano, e humanista, girando emum multiverso de códigos movimentados pelas materialidades de mídias em intersecções no contemporâneo.

\section{Palavras-chave}

Harun Farocki; montagem; magia; Schnittstelle.

\section{Abstract}

We perform an interpretation of Interface (1995), a work in which Harun Farocki seeks to understand his own gestures and environment, summoning us to make six brief reflections, which relate questions about film materialism, magic and montage in the context of industrial society. It is curious how the filmmaker unfolded his critical humanism. In it, images and words gain intense horizontality and transductions. A human, humanist world, spinning into a multiverse of codes moved by the materialities of media at intersections in the contemporary.

\section{Keywords}

Harun Farocki; montage; magic; Schnittstelle.

112 PORTO ALEGRE | v. 22 | n. 38 | 2017 | p. 112-120 DOl: http://dx.doi.org /10.15448/1980-3710.2017.2.25050 Sessões do Imaginário 


\section{Introdução}

No documentário/instalação Interface (Schnittstelle, 1995), o cineasta Harun Farocki (1944-2014) se põe a falar acerca de seu próprio trabalho e ambiente tecnológico, uma atitude que se mostrará produtiva para pensar, em sentido amplo, suas posições, métodos e estilos. Farocki quer, a partir disto, nos levar a refletir, sobretudo, sobre os fundamentos da montagem cinematográfica. Diferentes obras de sua carreira serão citadas, sendo analisadas e comparadas em trechos emblemáticos, reflexivos, empregando, para tanto, pela primeira vez, sua proposição de discurso visual denominada "montagem suave" (Farocki, 2013)². Ao analisarmos a referida obra, podemos estabelecer a presença de seis reflexões concisas. $O$ objetivo do artigo será precisamente explicitar tais reflexões, em breves análises.

\section{Materialidades analógicas e eletrônicas}

A primeira reflexão aborda as diferenças entre as materialidades analógicas e eletrônicas. Farocki quer definir, primeiramente, os caracteres peculiares dos ambientes de montagem. "Não posso escrever uma frase sem uma, duas imagens na tela" (Farocki, 1995). Ouvimos, de início, este conhecido comentário do cineasta, sabendo que o encontro do pensar literário e cinematográfico é uma de suas concepções estético-políticas fundamentais. Suas anotações começam pela análise da atitude do cinegrafista amador Paul Cozighian em Bucareste (imagens empregadas em Videogramas de uma revolução (Videogramme einer Revolution, Harun Farocki e Andrei Ujica, 1992). De seu apartamento, Cozighian havia contrastado a realidade que estava sendo midiatizada pela televisão estatal com aquilo que acontecia nas ruas. Farocki procura evidenciar como o pensar literário e cinematográfico podem se entrelaçar na materialidade do filme (analógico) e do vídeo (eletrônico). As imagens de Cozighian envolvem, pois, uma análise atenta daquilo que está "contido" nas imagens. As anotações vêm de tal processo. Assim, as imagens do trabalho em uma mesa de edição cinematográfica são comparadas com as da mesa de edição de vídeo. No primeiro caso, o trabalho com a película de cinema exige uma maior e mais complexa habilidade manual. Um manusear com referência à era mecânica o montador estabelece uma relação com correias de transmissão, máquinas de corte, alavancas, acessórios. No segundo caso, disposto na era eletrônica, vemos a mesa de edição eletrônica de vídeo, dispensando as funções manuais, principalmente de tato. No processo de montagem, explica Farocki (1995), faz-se um corte imaginário (virtual) na fita de vídeo - o montador fica imerso em um ambiente de trabalho a partir de teclas e botões bastante miniaturizados.

No paradigma da era mecânica, o filme é visto pela base material (essência), visível, tátil, da fita magnética, e o montador trabalha manualmente em uma projeção (aparência): essência e aparência se diferenciam, diz Farocki (1995); no paradigma da era eletrônica, com o vídeo eletrônico, o montador permanece em um vínculo visual abstrato. Extingue-se o contato tátil com a materialidade fílmica: essência e aparência coincidem.

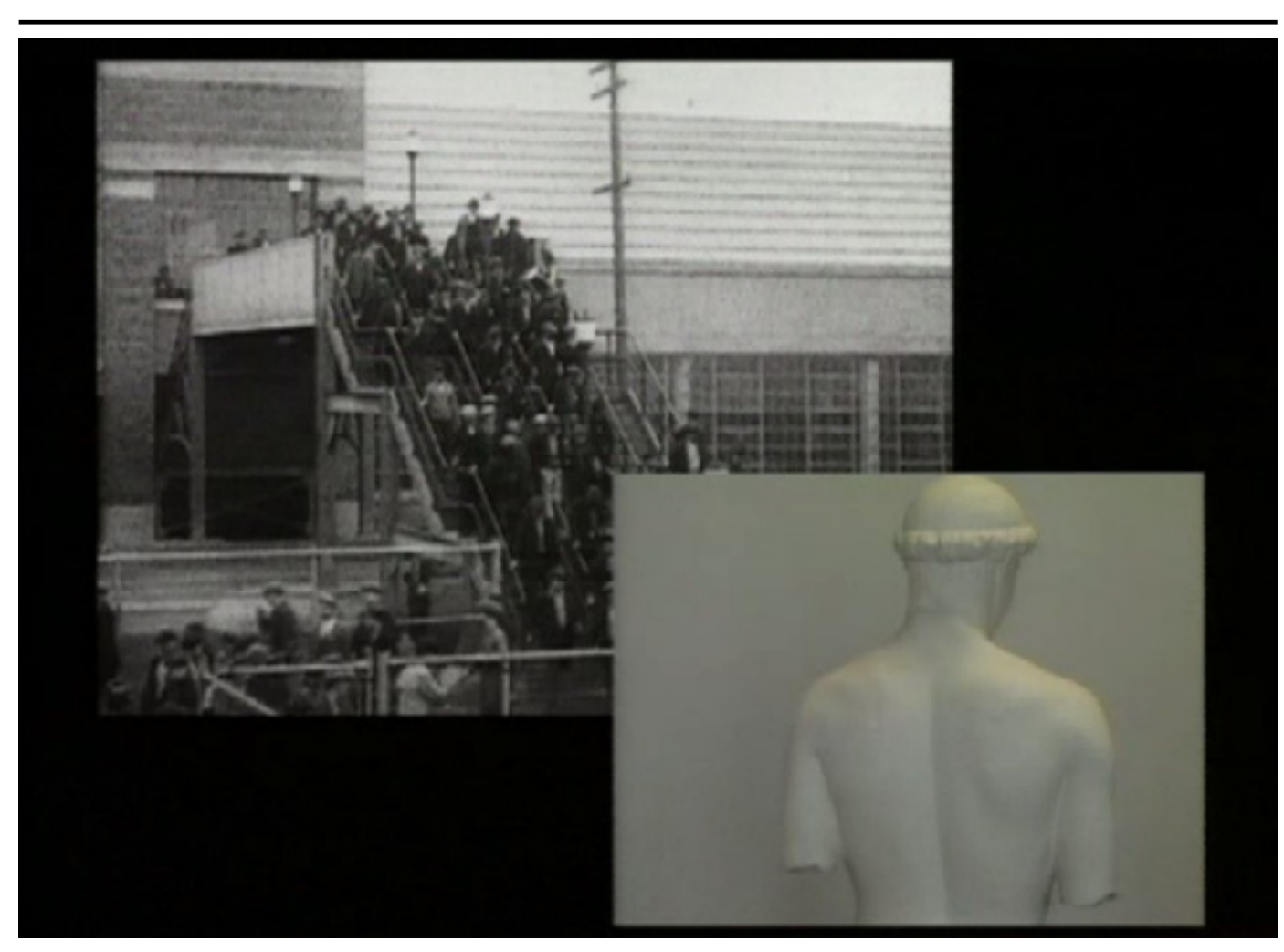

Figura 1: Materialidades analógicas e eletrônicas. Fonte: Farocki (1995).

113 PORTO ALEGRE | v. 22 | n. 38 | 2017 | p. 112-120 Sessões do Imaginário 


\section{Reminiscências}

Nos ambientes analógico e eletrônico surgem distintas formas de montagem e reminiscências. Como ligar uma imagem do passado à outra recente? Farocki (1995) conserva-se na mesa de edição eletrônica e explicita tal pergunta essencial do saber-fazer da montagem. Segue então a imagem de fita de vídeo VHS entrando no equipamento de leitura, que reproduzirá um trecho de Fogo Inextinguível (Nicht Löschbares Feuer, $\mathrm{Ha}$ run Farocki, 1969). A cena inicial desse filme, a demonstração da ação do Napalm a partir da queima de um cigarro no próprio punho, sendo ela comparada com o mesmo punho atual, ainda com a cicatriz daquele gesto. As duas imagens se ligam como "prova", passado e futuro de um gesto. Farocki repete "em eco" a leitura da denúncia do vietcongue. Tal gesto quer evidenciar o problema da representação da ação do Napalm na população, encarada naquela época: "Quando ele [o próprio cineasta] realiza esta fala, o autor queima a si mesmo, embora somente em um pequeno ponto. Aqui também [mostrando o punho], somente um pequeno ponto nos faz retornar ao mundo real" (Farocki, 1995).

Farocki quer nos mostrar a relação intrínseca entre a materialidade e a memória. Sobre isso, Rancière, refletindo sobre $O$ túmulo de Alexandre (Le tombeau d'Ale- xandre, 1993), documentário de Chris Marker, ajuda-nos a compreender:

Comecemos por algumas evidências que, para alguns, ainda podem parecer paradoxais. Uma memória não é um conjunto de lembranças da consciência. [Com esta afirmação] [...] a própria ideia de memória coletiva seria vazia de sentido. A memória é um certo conjunto, um certo arranjo de signos, de vestígios, de monumentos. O túmulo por excelência, a Grande Pirâmide, não guarda a memória de Quéops. Ele é essa memória (2010, p. 179).

A reflexão de Rancière parece traduzir bem a posição de Farocki no ambiente de montagem cinematográfica. Os signos, vestígios, monumentos e, custa lembrar, obviamente, as tecnologias comunicacionais diversas, são "memórias técnicas": constituem dispositivos que transportam, como suportes, a memória da humanidade. No mundo moderno, a imagem técnica, especificamente, esta exterioridade midiática tão poderosa, surgida a partir de diferentes tipos de máquinas fotográficas e cinematográficas, afirma-se enquanto materialidade e memória, sendo capaz de evidenciar ou criar acontecimentos: capaz de produzir e se confundir com a memória ou, caso se queira, a História. A partir de seus próprios filmes, Farocki quer nos apresentar, pois, particulares evidências disso.

\section{Experimento científico?}

"A montagem poderia ser equiparada a um ex-

Figura 2: Montagem e reminiscências. Fonte: Farocki (1995). perimento científico?" (Farocki, 1995). A pergunta de Farocki demarca uma curta terceira reflexão - a ser desdobrada após, na quinta e na sexta -, a do valor

114 PORTO ALEGRE | v. 22 | n. 38 | 2017 | p. 112-120 Sessões do Imaginário 
do saber-fazer da montagem na relação entre o sujeito e as materialidades de mídia; e ele imediatamente nos dá uma razão para sua resposta negativa: "No experimento científico não pode haver contato manual; a ciência moderna é puramente intelectual" (Farocki, 1995).

Ao mesmo tempo em que apresenta tal consideração, a sala de montagem é tomada por uma cortina de fumaça, levando-nos inevitavelmente a reconhecer sua indagação e proposição implícitas: ora, o pensar-operar aqui é indissociável de um fazer manual. Ora, o montador não estaria aberto a ser, antes de tudo, um xamânico moderno em invés de um cientista? A imagem do laboratório simulador de ondas de Imagens do mundo e inscrições da guerra (Bilder der Welt und Inschrift des Krieges, Harun Farocki, 1988) surge então em paralelo à outra: a imagem das mãos de Farocki apoiadas nas pernas, reforçando a ideia precedente, a saber: neste experimento tecnológico-científico, revoga-se o contato corporal; em outras palavras, revoga-se o pensar-operar-manual.

\section{Montagem e sociedade industrial}

Recuperando imagens de Trabalhadores saindo da fábrica (Arbeiter verlassen die Fabrik, Harun Farocki, 1995), Farocki busca destacar a dimensão mais ampla de tal revogação de pensar-operar-manual, a partir do exame de um arquétipo da sociedade industrial. Qual seria o arquétipo fisionômico da sociedade industrial? Enfrentando a intricada pergunta, ele nos faz compreender que se observássemos como procederam os historiadores da arte, poderíamos ter um aporte comparativo, pois estes evidenciaram uma mudança de paradigma na representação estética, evidenciada na estátua grega antiga Efebo de Crítio ${ }^{3}$. Nesta estátua, pela primeira vez uma representação humana apresentava uma diferença de pesos e expressões das pernas e dos ombros, entre os lados do corpo relaxado e do que sustenta.
Surge uma isonomia não tão regular, portanto. Teria sido assim que os gregos expressaram na arte o sentido de liberdade que eles queriam que houvesse no corpo da pessoa citadina. Contudo, na sociedade industrial, ou melhor, nas imagens do portão da fábrica da Ford do início do século $X$ vemos os proletários saindo, de modo que observamos uma dimensão "pré-Crítios": "uma isonomia muito regular".

Ora, o anseio da montagem de Farocki é exatamente o de produzir o comum, mas não tão regular. Ora, é necessário a produção da diferença. A questão específica será a de uma conversão, em algo positivo, do mundo tecnificado, inescapavelmente presente na montagem. Um arranjo burocrático qualquer não implicaria, por mais que os dispositivos estivessem acoplados a uma armação tecnocapitalista, em um horizonte já decidido, isonômico, de calculabilidade da vida. Em qualquer universo, existiria espaços para liberação "mágica"; em outras palavras: um espaço capaz de desautomatizações e transindividuações.

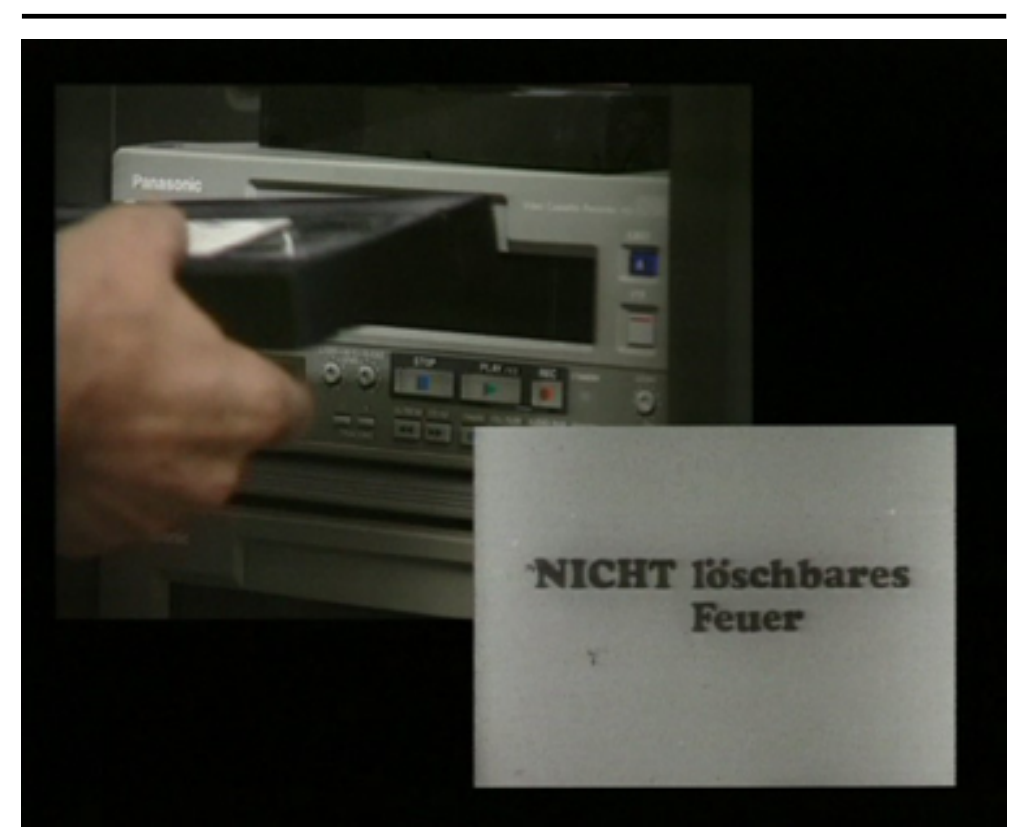

Figura 3: Laboratório de montagem e laboratorio técnico-científico. Fonte: Farocki (1995).
115 PORTO ALEGRE | v. 22 | n. 38 | 2017 | p. 112-120 Sessões do Imaginário

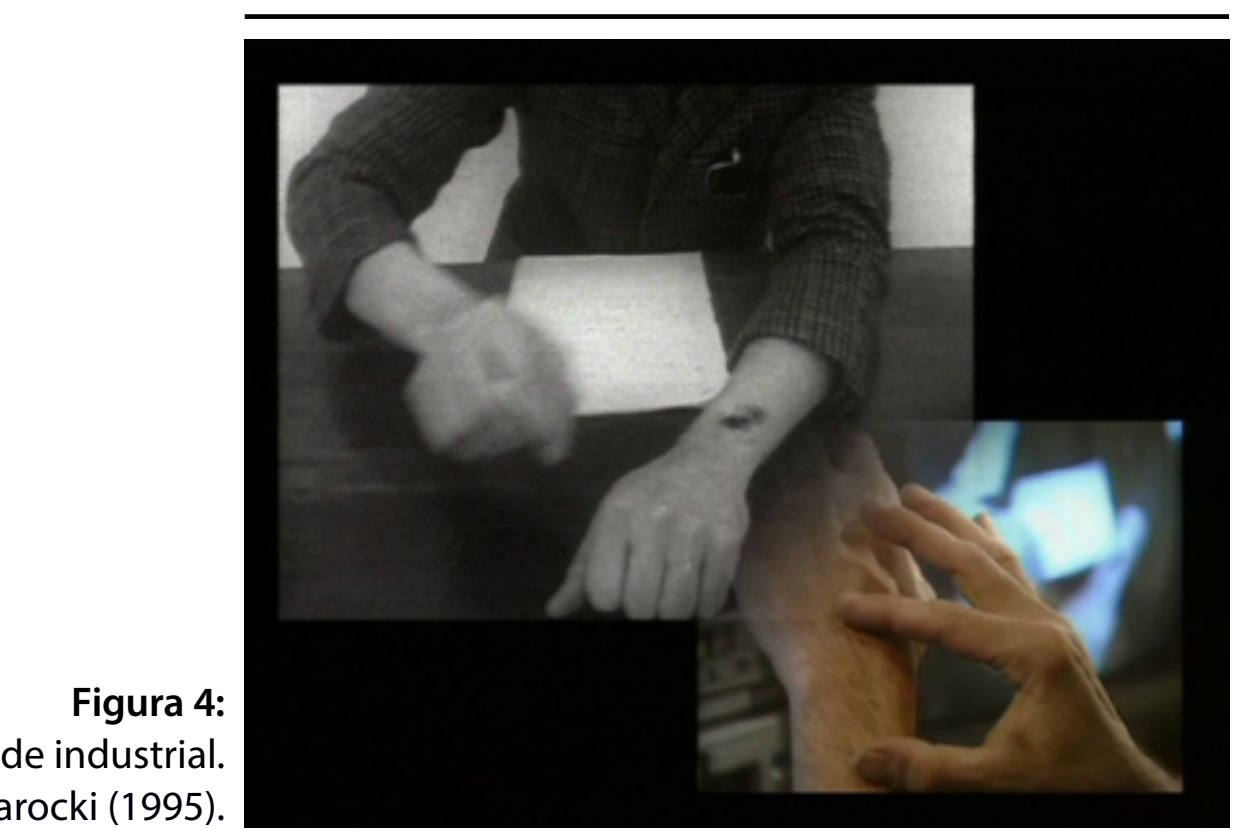

Fonte: Farocki (1995) 


\section{Modelo pós-semântico}

A montagem poderia ser equiparada a um experimento científico? Voltamos à questão intricada da terceira reflexão, agora para explicitamente destacar o caráter mágico que ele nos havia aludido. Em 1977, durante a realização de seu filme Entre duas guerras (Zwischen zwei Kriegen, Harun Farocki, 1978), teríamos uma autorreflexão acerca da "montagem de ideias". Nesta ficção, não apenas a pós-produção na sala de montagem, mas o próprio roteiro e cenário satisfaziam isso. O cineasta nos exibe a cena emblemática e reflexiva em que o próprio está com tesoura em punho, fazendo recortes fotográficos sob a mesa e anunciando as conjunturas e premissas de um montador "independente" mesmo dentro de um adverso contexto artístico e político-tecnológico da Alemanha Ocidental daquela época. Ao rememorar tal passagem do filme, comenta: "Às vezes eu acho que aprendi coisas na sala de montagem que nunca saberei explicar a ninguém, como os matemáticos que não podem encontrar alguém para contar sobre seu trabalho" (Farocki, 1995). Veremos então o fazer manual-técnico do montador, em seu "demorado processo", minucioso, de análise e transferência de imagens de um display a outro, sem ainda dispor da adição de comentários verbais-textuais. Sabemos, a montagem não tem a ver verdadeiramente com a gramática, com leis, premissas... De tal modo, como explicitar o fundamento de tal "fazer"? De forma científica? Ou mágica?

Farocki localizará corretamente o ponto de referência histórico mais significativo para encarar as indagações acima, procurando aproximar o operar da montagem cinematográfica e o operar da máquina criptográfica Enigma, criada por Alan Turing para ser usada como instrumento de espionagem pela Inglat- erra na II Guerra Mundial. A partir de imagens de suas mãos utilizando tal máquina, comenta:

Quando você tecla na máquina [Enigma], você dispara um impulso elétrico que viaja por um certo caminho, de acordo com a posição do cilindro, e permite a iluminação de uma letra diferente. Durante a II Guerra Mundial, a Inglaterra teve sucesso em construir uma máquina capaz de quebrar o código alemão. Liderado por Alan Turing, eles construíram uma mega-calculadora, a qual foi significativa para o desenvolvimento do computador. Alan Turing se encantava em perceber o intelecto humano como uma máquina. Ele desejava que ele mesmo pensasse como uma máquina (Farocki, 1995).
Enigma produziria uma espécie de "maiêutica instrumental", isto é, um conhecimento gestado francamente em conexão com a máquina, estando inseparável das regras de permutação, combinação, recombinação que o "programa providencia e ordena" (Farocki, 1995). A máquina utiliza os códigos de uma forma que alterna racionalidade e misteriosidade, industrialismo e magicismo, constituindo, antes de tudo, uma moderna máquina de codificação-e-descodificação, a partir de um modelo póssemântico preconizado pelo protótipo do código Morse ${ }^{4}$. A máquina de Turing constituía, portanto, outro exemplo para discorrer sobre o caráter do horizonte maquínico da modernidade, que, tal como Farocki lembrava, Kafka já havia compreendido: "Franz Kafka contribuiu para destacar que [o bureau; a oficina] atende principalmente a uma função mágica" (Farocki, 2013, p. 81, grifos nossos)5.

116 PORTO ALEGRE | v. 22 | n. 38 | 2017 | p. 112-120 Sessões do Imaginário

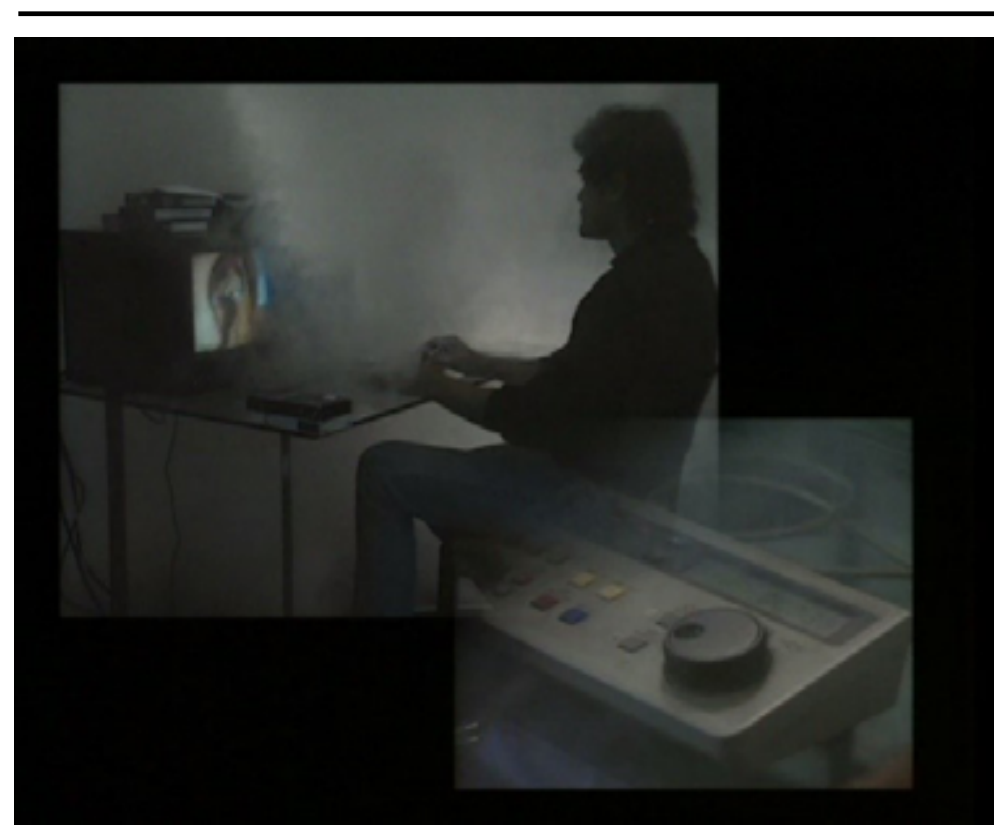

Figura 5: Modelo pós-semântico e código Morse. Fonte: Farocki (1995). 


\section{Montagem e magia}

Chegamos à última reflexão de Interface, lugar em que Farocki avança em suas reflexões sobre a relação montagem e magia. $O$ século $X X$, como sabemos, disseminou a nova tecnicidade "foto-cine-fono-gráfica como suporte da memória". Uma tecnicidade investida em máquina de codificação-descodificação, de reprodução analógica e digital, permitindo processos de descrição, formalização e discretização espacial-temporal dos comportamentos humanos (linguagem, gesto, cálculo). Tal fato, que representou uma mudança nas formas de memória, antes baseada em suporte da memória literária, teria, profundamente, modificado o valor da Bildung constituída no século XIX ${ }^{6}$.

Farocki (1995) - ele nos diz expressamente - não pretende realizar uma digressão em relação ao seu tema central quando segue comentando alguns contextos da vida e da inovação de Alan Turing. $O$ interesse continua o mesmo: a apreensão do que vem a ser a montagem cinematográfica originada a partir deste novo "fazer" manual-técnico. $O$ cineasta tinha notado, a partir de Kafka, como vimos, o significado da sala de montagem como uma "oficina", enfatizando a etimologia que liga "oficina" e a palavra francesa bureau; e notando, com isso, que o ambiente de "burocracia" não deixa de ter também a capacidade de efetivar novas produções de "sentidos". A produção de sentido na montagem é então vista no campo da "analítica de transferência" (Farocki, 1995) - ou, como interpretamos, como "operar transindividual", a partir de códigos (Galloway, 2004)7.

Ao comentar o videomaker Bil Viola, Garcia dos Santos assevera: "Viola é um xamã que recorre às máquinas eletrônicas como o feiticeiro dispõe de um arsenal de objetos e fetiches para invocar as forças e as potências, e canalizá-las com o intuito de empreender uma trans- formação" (apud Ferreira, 2006, p. 9), carecendo, com isso, compreender que os xamãs "[...] não são uma mistificação das máquinas, mas sim uma tecnologização da mística, uma concretização tecnológica [...]" (Ferreira, 2006, p. 225). Estudando o operar dos DJs (Disc Jockeys) de música eletrônica, Ferreira nota como o xamanismo, enquanto "técnica do êxtase", opera e conjuga ritos e tecnicidades na produção de música. No cineasta-montador Farocki, a questão poderia ser pensar como seu operar com o universo dos códigos eletrônicos se desdobra em xamanismo, movimentando "[...] um conjunto de técnicas de 'comutação de perspectivas' radicadas no corpo concebido como habitus ('um conjunto de maneiras ou modos de ser'), [um] 'feixe de afecções e capacidades', 'origem das perspectivas' [...]"' (Ferreira, 2006, p. 233, grifos do autor).

Ora, a arte não se faz sem os suportes, ferramentas, máquinas, nem sem as sistematizações, proposições abstratas. A noção de tecnoestética esclareceria a relação entre o "saber-inventar" (estética) e o "saber-fazer" (técnica) enquanto duas "fases" ${ }^{\prime \prime}$ de pensar transindividual, permitindo alargar a noção de estética: não apenas a obra de arte é passível de "estetização", mas qualquer ato, objeto, pode ser atribuído um valor estético. Em sua obra Do modo de existência dos objetos técnicos (2007), Simondon avançou a respeito, ao pensar a "magia" enquanto a unidade antropológica básica, "primitiva", em que o ser humano se relaciona com o mundo, a partir da técnica. Simondon amplia a compreensão do que vem a ser a relação entre estética e técnica, a partir do "operar mágico" . Para ele, o pensamento estético não é "um domínio limitado nem uma espécie determinada, mas somente uma tendência" $\left(2007\right.$, p. 197) ${ }^{10}$, que qualifica um pensar transindividual. Os códigos - as informações, para Simondon - se relacionam a partir das transduções, a partir das intuições, imaginações, percepções, sensações. Aqui, não é a arte enquanto objeto institucionalizado ou o gosto do espectador que está sendo expresso, mas sim as operações com os códigos realizadas pelo pensar estético.

Tais pensamentos ensejam o que, em última instância, Farocki acreditava e praticava em suas obras: um ambiente mágico; um lugar de surgimento de modulações, diferenças; ou seja: de transindividuação. Interface vivifica, de modo conduzido e cabal, aquilo que a obra que Farocki procurou precisamente movimentar, o operar transindividual na montagem, situação francamente reflexiva e prática, de resguardo da natureza indecidível, aberta, com vista a clarear uma situação e posição políticas no mundo. Na montagem, a presença da materialidade tecnológica ("burocrática") não deixa de ser um espaço de produção de sentido; ora, é nela mesma que o real - a produção do acontecer, "midiático" - ganha fundamento.

O cineasta nos deixa duas derradeiras interrogações: "Esta sala de montagem seria um codificador ou um decodificador?"; "Estaríamos diante de um decodificador de segredos ou um codificador?" (Farocki, 1995). Reflexão evidente para quem se fez perceber mais longe de um pensar científico; mais próximo de um pensar "xamânico maquínico".

Farocki desperta curiosidade pela forma como desdobrou o humanismo crítico do qual herdou. Imagens e palavras já ganham horizontalidade e transduções. Um mundo humano, e humanista, já "fora do livro"; ou melhor, dentro do livro, mas também em um multiverso de "códigos" movimentados pelas materialidades de mídias em "intersecções"11 no contemporâneo. 


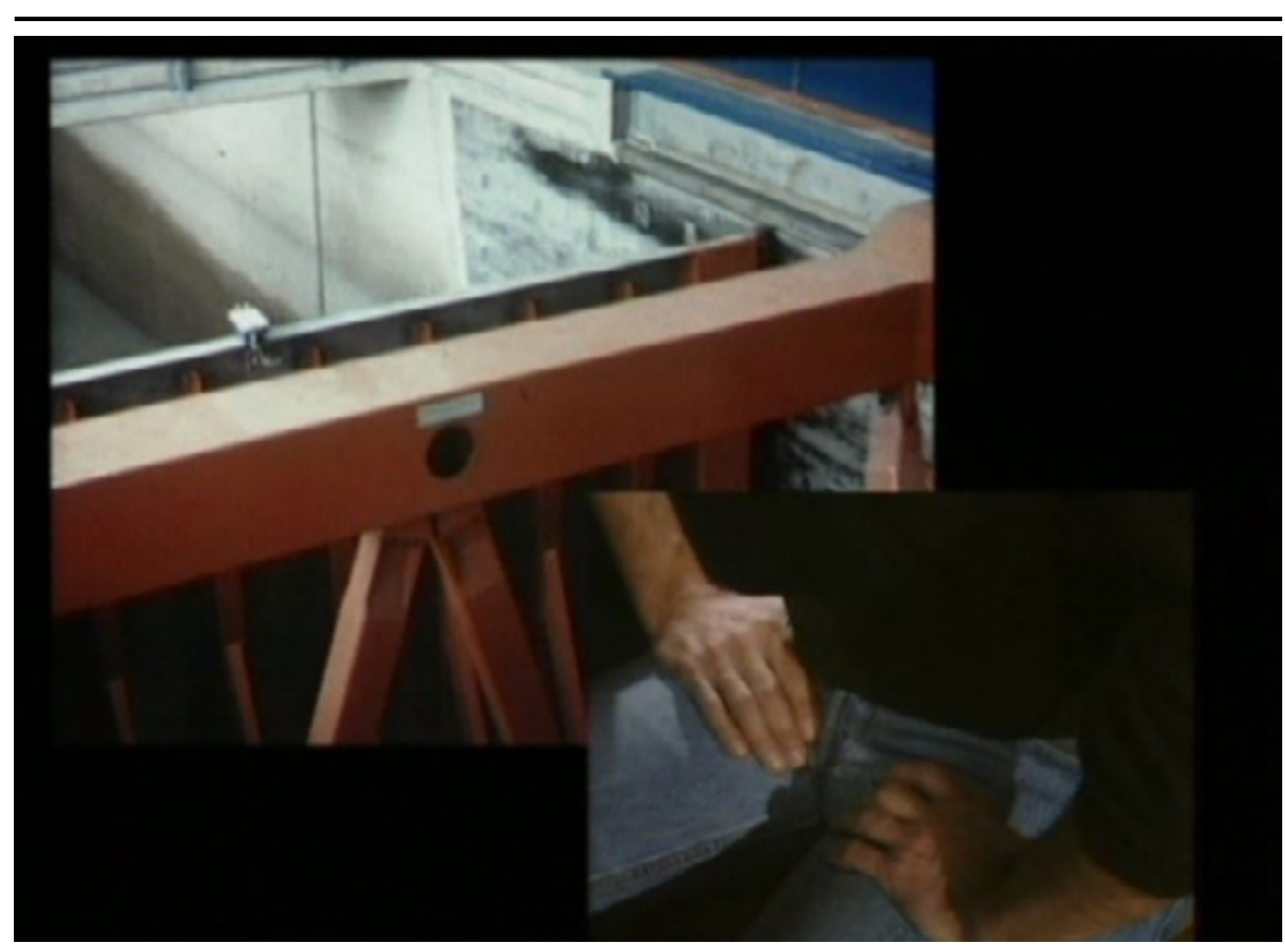

Figura 6: Um operador-montador-xamanista? Fonte: Farocki (1995).
Referências

FAROCKI, Harun. Desconfiar de las imágenes. Buenos Aires: Caja Negra, 2013.

FERREIRA, Pedro P. Música eletrônica e xamanismo: técnicas contemporâneas do êxtase. 2006. 498 f. Tese (Doutorado em Sociologia). Programa de Pós-graduação em Sociologia. UNICAMP, Campinas, 2006.

GALLOWAY, Alexander. How control exists after decentralization. London: MIT Press, 2004.

HOUAISS, Antônio. Dicionário Houaiss da Língua Portuguesa. Rio de Janeiro: Ed. Objetiva, 2001.

KITTLER, Friedrich. Gramophone, film, typewriter. Stanford: Stanford University Press, 1999.

RANCIÈRE, Jacques. A ficção documental: Marker e a ficção da memória. Arte \& Ensaios, Rio de Janeiro, $n^{\circ} 21$, p. 179-189, dez. 2010. Disponível em: <http://www.ppgav.eba.ufr.br/wp-content/uploads/2012/01/ae21_Jacques_Ranciere.pdf $>$. Acesso em: 02 jul. 2016

RODRIGUES, Jorge H. V. Friedrich A. Kittler, filósofo da tecnologia: uma tradução comentada. 2013. 256 f. Dissertação (Mestrado em Ciências da Comunicação). Faculdade de Ciências Sociais e Humanas, Universidade Nova de Lisboa, Lisboa, 2013.

SIMONDON, Gilbert. El modo de existencia de los objetos técnicos. Buenos Aires: Prometeo Livros, 2007. 


\section{Referências audiovisuais}

BAUTE, Christian. MIS, Heinrich. FAROCKI, Harun. Traba-

Ihadores saindo da fábrica. [Filme-vídeo]. Produção de Christian Baute, Heinrich Mis e Harun Farocki. Direção de Harun Faorcki. Alemanha, Harun Farocki Filmproduktion, 1995. $36 \mathrm{~min}$. Color. P \& B. Son.

FAROCKI, Harun. Entre duas guerras. [filme]. Produção e direção de Harun Farocki. Alemanha, Harun Farocki Filmproduktion, 1978.83 min. P \& B. Son.

Fogo inextinguível. [filme]. Produção e direção de Harun Farocki. Alemanha, Deutsche Film und Fernesehakademie Berlin, 1969. 28 min. P \& B. Son.

Imagens do mundo e inscrições da guerra. [Filme]. Produção e direção de Harun Farocki. Alemanha, Harun Farocki Filmproduktion, 1988. 75 min. Color. $P \& B$. Son.

Interface. [Filme-vídeo]. Produção e direção de Harun Farocki. Alemanha, Musée d'art moderne villeneuve d'Ascq e Harun Farocki Filmproduktion, 1995. 23 min. Color. Son.

FAROCKI, Harun; UJICA, Andrei. Videogramas de uma revolução. [Filme-vídeo]. Produção de Harun Farocki. Direção de Harun Farocki e Andrei Ujica. Alemanha/ Romênia, Bremen Institut und Fernsehen e Harun Farocki Filmproduktion, 1992. 106 min. Color. Son.

KUSTOW, Michael. MARKER, Chris. O túmulo de Alexandre. [Filme-vídeo]. Produção de Michael Kustow. Direção de Chris Marker. França/Finlândia, Les Films de I'Astrophore, La Sept, Centre National de la Cinémato- graphie e Epidem, 1993. 120 min. Color. Son.

MARKER, Chris. Sem sol. [Filme]. Produção e direção de Chris Marker. França, Argos Films, 1983. 104 min. Color. P \& B. Son

\section{Notas}

1 Doutor em Comunicação pela Universidade Federal Fluminense (2015). Mestre em Sociologia Política pela Universidade Federal de Santa Catarina (2010). Professor Substituto de Ciências Sociais pela Universidade Federal de Mato Grosso do Sul (UFMS - Campus de Naviraí. Rodovia MS 141, s/n. - 24210590 - Naviraí, MS Brasil - Caixa-postal: 79950000).E-mail: ednei.genaro@ yahoo.com.br.

2 Em sua concepção de montagem suave (weich montage), Farocki busca acondicionamentos sincrônicos e/ ou diacrônicos na montagem. A partir de duas telas lado a lado, ou a partir de repartição de duas imagens em uma tela, dividindo e transcorrendo sucessivas imagens duplas, em acúmulo contínuo e comparativo (Farocki, 2013).

3 O torso, encontrado em Acrópole de Atenas em 1864, atribuído ao escultor Crítio, vivido no início do século V a.C., é considerado a mais antiga representação da postura em contrapposto, que marca o rompimento da simetria e frontalidade na representação de corpos e define o fim do período Arcaico na escultura.

4 "[Com o protótipo de Morse], pela primeira vez uma escrita era optimizada com base em critérios técnicos, sem consideração pela semântica, embora não fosse ainda chamada de Código Morse. [...] Desde então chama-se 'descodificar' e 'codificar', àquilo que outrora se designava como 'decifrar' e 'cifrar'. Todo o código que o computador hoje em dia processa está sujeito portanto ao teste de Kolmogorov: é mau todo o input que é em si mesmo mais extenso que o seu output; no caso do 'ruído branco' são os dois igualmente extensos; finalmente, o código é elegante quando o seu output é muito mais longo do que ele próprio. O século vinte fez assim do Code Condenser, como uma espécie de alto princípio economicista do capitalismo, a plena consumação do rigor matemático" (Kittler apud Rodrigues, 2013, p. 118).

5 No original: "Franz Kafka contribuyó a poner de manifiesto que cumple, principalmente, una función mágica".

6 Sobre isso, Kittler lembraria e responderia àquela pergunta intencionalmente ingênua de Chris Marker, em Sans Soleil (1983): "Perdido no fim do mundo na minha ilha, Sal, na companhia dos meus cães que vagueiam, lembro-me daquele janeiro em Tóquio, ou melhor, lembro-me das imagens que filmei em janeiro em Tóquio. Elas se estabeleceram no lugar das minhas memórias, elas são as minhas memórias. Perguntome como se lembram as pessoas que não filmam, que não fotografam, que não registam sons; como é que a humanidade procedia para se lembrar" (Marker apud Kittler, 1999, p. 10). Ora, responderá Kittler (1999, p. 10) em seguida, os "alfabetizados perfeitos de 1800", isto é, estes dignitários de Goethe, Schiller e Cia. foram os que, naquela época, magnificamente exerceram e divulgaram todo o valor de reminiscência com a técnica da escrita. 
7 Longe de uma definição semântica, um código - explica Galloway (2004, p. 13): "[...] é um processo básico: ele é analisado, compilado, processado ou orientado a objetos, e definido por padrões ontológicos [...]. É um circuito, não uma sentença. Código não é necessariamente uma linguagem; e certamente também não é um signo. Um código é uma série de engrenagens mecânicas ativadas, ou uma pilha de cartões perfurados que circulam através de uma máquina de leitura, ou um fluxo de pulsos-de-luz ou bits em um transistor ou em silício, ou um barril de interacções de ligação entre fragmentos de DNA".

8 Nos termos de Simondon (2007): não há arte sem as "figuras" (modos teórico/prático "técnicos") e "fundos" (modos teórico/prático "religioso").

9 No pensamento operativo transindividual de Simondon, a magia é "[...] uma estruturação que resolve provisoriamente os problemas colocados na fase primitiva e original da relação do homem com o mundo. Pode-se denominar esta primeira fase de fase mágica, tomando esta palavra no sentido mais geral e considerando o modo mágico de existência como aquele que é pré-técnico e pré-religioso" (2007, p. 173; no original: "[...] una estructuración que resuelve provisoriamente los problemas planteados por la fase primitiva y original de la relación elel hombre con el mundo. Se puede denominar a esta primera fase la fase mági$\mathrm{ca}$, tomando esta palabra en e1 sentido más general y considerando el modo mágico de existencia como aquel que es pretécnico y pre-religioso $\left.[. . .]^{\prime \prime}\right)$.

10 No original: "[...] al pensamiento estético, nunca per tenece a un dominio limitado o de una espécie parti-

120 PORTO ALEGRE | v. 22 | n. 38 | 2017 | p. 112-120 Sessões do Imaginário cular, sino sólo a una tendencia"

11 Talvez uma tradução possível para Schnittstelle. Intersecção - "rubrica matemática: operação pela qual se obtém o conjunto formado pelos elementos comuns a dois outros conjuntos" (Houaiss, 2001). 